\title{
GIS ANALYSIS OF ROAD NETWORK ACCESSIBILITY FOR EMERGENCIES MANAGED BY FIREFIGHTERS (CASE STUDY - SUCEAVA COUNTY, ROMANIA)
}

DOI: https://doi.org/10.18509/AGB.2017.08

UDC: 004:528.9]:656.1:614.84(498.1)

\author{
Diana-Sofia Graur ${ }^{1}$, Vasile Efros ${ }^{2}$ \\ 1,2“Stefan cel Mare” University of Suceava, Faculty of History and Geography, \\ Department of Geography, Suceava, Romania
}

Corresponding author: dianasophiagraur@yahoo.com

Submitted: January 2017, Accepted: May 2017, Published: August 2017

\begin{abstract}
Emergencies represent inevitable problems of contemporary society. They have a specific difficulty level determined by a multitude of factors. For these reasons we proposed to do a study on emergencies accessibility within a geographic area with a specific category of risk, considering it useful and topical, but also a solid ground to elaborate this sort of analysis.

The purpose of the present paper is to demonstrate the way in which the GIS technology can help the emergency services achieve the optimal level to solve every emergency as effectively as possible.

Among the goals of this study is deploying modern methods and techniques of cartographic analysis to achieve cartographic and statistical results that will visually expose and quantify the level of accessibility of Suceava county population to various emergency services, depending on the geographic position of each locality and its assignation toward the closest professional intervention service in emergency situations.

In this context, it becomes particularly important the demonstration the applicability of modern techniques of GIS usage and their implementation in various surveys, which can generate differentiations on categories between several zones of investigated area, based on factor analysis and of favorability of the zone analyzed related to the points of interest in the immediate vicinity.
\end{abstract}

Key words: GIS, fire, emergency, road networks, response time;

\section{Introduction}

The mission of the emergency services is to protect life, propriety and natural resources from fires and other emergency situations [1]. Due to the increase in incidents, the emergency services institutions have to use the best instruments, techniques and training methods to meet public expectations. One of the tools that helps improve the emergency services institutions is the Geographic Information System (GIS).

Emergency services rely on spatial data. The rescue personnel units have to know where each unit and available resources are located, for example, the position of the incident, the environment and the available resources for the intervention. They play a crucial role in the public safety of every community, their availability being highly dependent on the location of the incidents and the fastest route to them. Their performance should be as efficient as possible to ensure the safety of as many lives as possible.

There are many other ways to approach the problem of ambulance allocation using GIS, and can be found in the theses of [2] Lindeskov, C.K. (2002), [3] Sapateiro C., Antunes P. (2009), [4] Vratonjić M., Wittmann H. (2015).

GIS supports the planning, preparation, mitigation, the response, and management of incidents [1]. It also extends the capacity of maps (intelligent, interactive) to include all kinds of information, analyses, and data. 
When an emergency situation occurs, any delay in the intervention of authorized institutions can make the difference between salvation, serious injury or loss of human life. GIS helps reduce response time and increases efficiency.

The area studied here is located in northeastern Romania, bordering to the north with

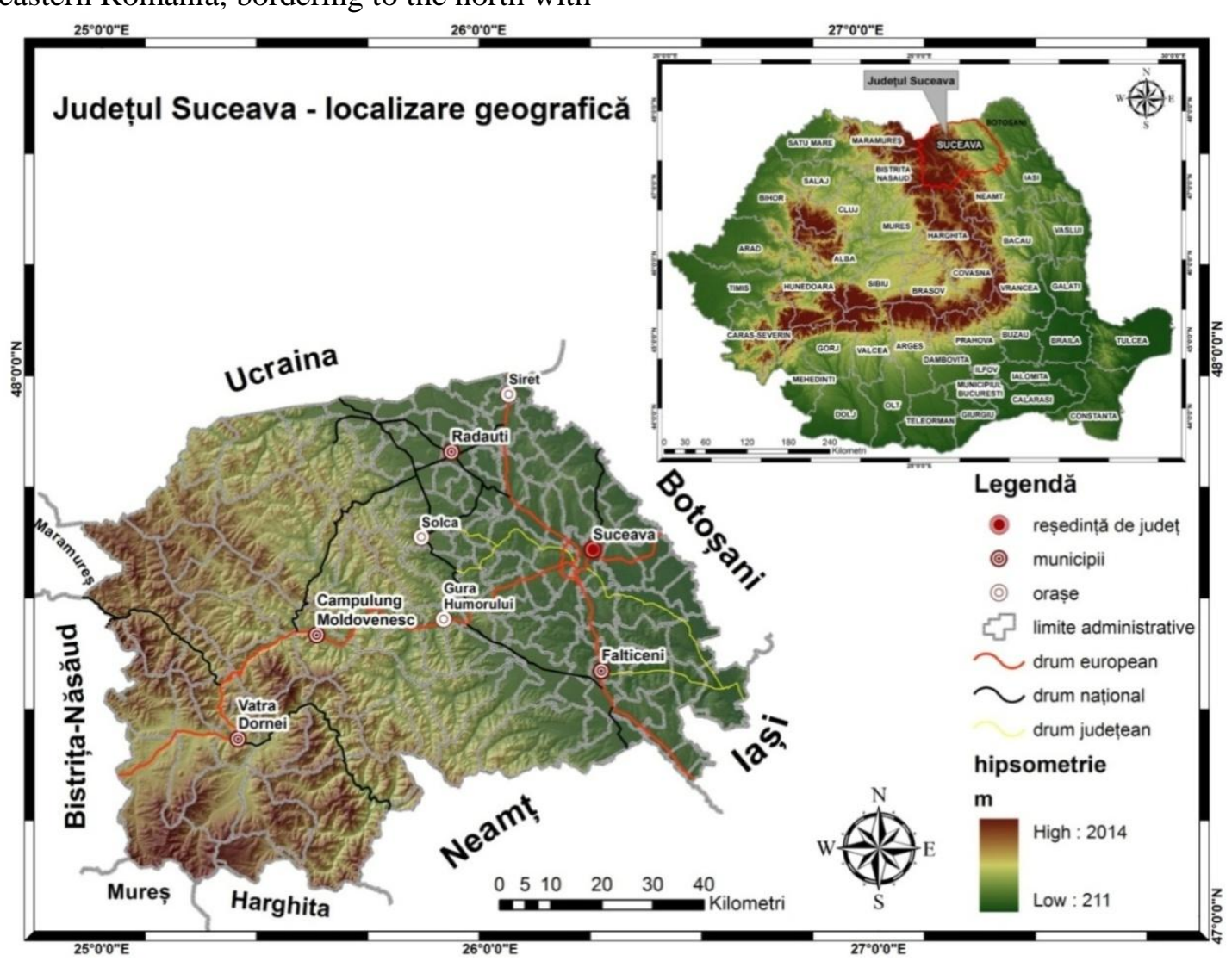

Figure 1: The geographical location of Suceava county.

\section{Materials and methods}

The main research methods used in this study are: bibliographical, cartographical, and statistical methods.

For the extraction of the information necessary to create the routes and maps, the necessary steps taken were as follows:

- The delimitation of the studied area;

- The extraction of the necessary information through vectorization:

\section{$\circ$ Zone limit;}

$\circ$ Road network;

○ Railroads;

○ Emergency units locations;

- Creating of service areas;
Ukraine, to the east with Botoșani County, to the southeast with Iași County, to the south with Neamț, Harghita and Mureș counties, and to the northwest with Bistriţa-Năsăud and Maramureș counties. (Fig.1) 
tables with the population of the area were extracted from the INSSE 2011 census.

For the present cartographical analysis, we resorted to the implementation of the GIS cartographical analysis technique, particularly the use of the Network Analysis function [5].

The 2005, 2008 and 2010 orthophoto plans, taken from the National Agency for Cadastral and Land Registration, were used to obtain the necessary information for the study through vectorization, resulting in the creation of the shape files, the road network, and railways (polyline), limiting study area (polygon), and emergency services locations (point).

\section{Results}

The aims of this paper can be found in the generation of cartographical products which expose the areas of operation and in resolving problems posed by certain restrictions/ barriers to facilitate the activity the emergency services in Suceava County. These objectives were achieved through the use of the Network Analyst extension.

A case of emergency itself is an unpredictable situation, something that doesn't allow the localization and prevention of potential emergencies, therefore, emergency services have to make use of every means at their disposal to respond as efficiently as possible in emergency situations. Because both time and distance are very important in the case of emergency services, the cartographic analyses of the present study were conducted in order to select the unit closest to the location of the incident, regardless of its location within the county.

The areas of operation for emergency situations were conceived based on the time it takes the Emergency Situation Services to arrive at the location of the accident regardless of its location within the county. Currently, the optimal time it takes an ambulance to reach the site of an incident varies between 10 and 20 minutes.

The identification of a service area can be realized using the recently developed meth-

\footnotetext{
${ }^{2}$ Institutul Național de Statistică (National Institute of Statistics).
}

ods for network vulnerability analysis, as described in [6].

Sub-units of professional military firefighters are deployed in major urban areas of the examined areas territory: the municipalities of Suceava, Rădăuți, Fălticeni, Câmpulung Moldovenesc, Vatra Dornei and in the cities of Gura Humorului, Siret, Vicovu de Sus and Solca. (Fig.2)

In the case of the service area for fires, firefighter units have in their possession, for every city, specialized technical equipment: fire engines, mobile platforms and mobile ladders for interventions in high places.

The administrative units most affected by the lack of professional equipment and facilities for emergency intervention against fires are:

Ulma, Moldovița, Izvoarele Sucevei, Moldova-Sulița, Cârlibaba, Breaza, Poiana Stampei, Panaci, Broșteni, part of Crucea, Ostra, Mălini and Dolhasca.

On the basis of the cartographic products referring to the intervention time of the firefighters services in emergency situations in Suceava county, we centralized statistical data which express on the whole, in a valoric way, the coverage degree and the intervention time of the firefighters services in Suceava county, related to area and number of inhabitants. 


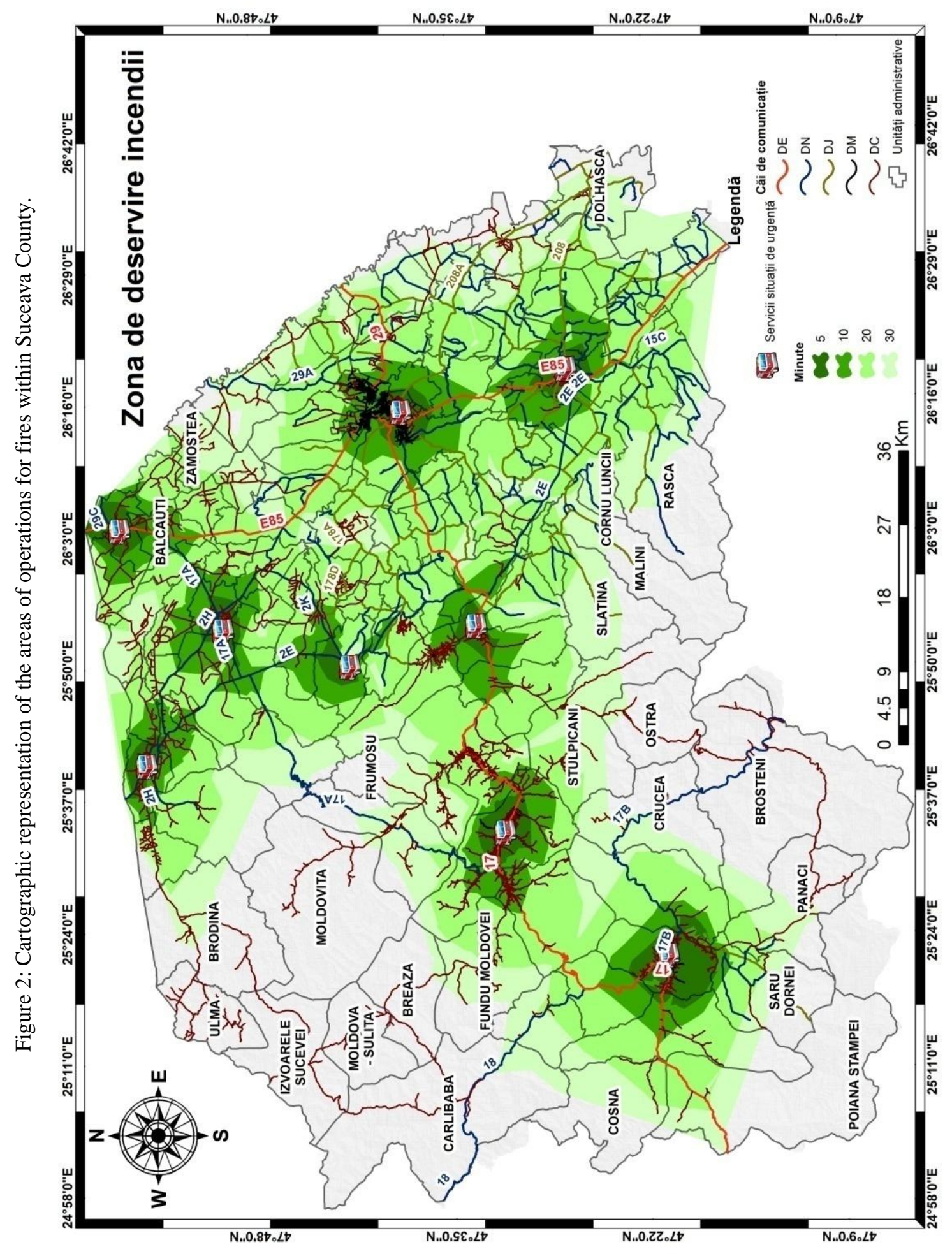


Table 1: Statistical report on the access of the population to the services of the firefighters.

\begin{tabular}{|c|r|r|r|r|r|r|r|r|}
\hline $\begin{array}{c}\text { Intervention } \\
\text { time (minutes) }\end{array}$ & 5 & 10 & 15 & 20 & 25 & 30 & $>30$ & Total \\
\hline $\begin{array}{c}\text { Number of } \\
\text { inhabitants }\end{array}$ & 209956 & 44032 & 69749 & 138259 & 47182 & 98695 & 22960 & 630833 \\
\hline$\%$ inhabitants & 33.28 & 6.98 & 11.06 & 21.92 & 7.48 & 15.65 & 3.64 & 8 \\
\hline $\begin{array}{c}\text { Number of } \\
\text { administrative } \\
\text { units }\end{array}$ & 9 & 9 & 14 & 37 & 11 & 23 & 111 \\
\hline $\begin{array}{c}\% \text { administrative } \\
\text { units }\end{array}$ & 8.11 & 8.11 & 12.61 & 33.33 & 9.91 & 20.72 & 7.21 & \\
\hline Surface & 544.76 & 374.44 & 688.44 & 1916.47 & 811.49 & 2489.09 & 1698.85 & 8523.54 \\
\hline$\%$ surface & 6.39 & 4.39 & 8.08 & 22.48 & 9.52 & 29.20 & 19.93 & \\
\hline
\end{tabular}

Source: 2011 Census

Thus, according to Table 1 , only $33.28 \%$ of the population of Suceava county, namely a total of 209,956 inhabitants, benefit from rapid service in case of a fire emergency. The degree of territorial coverage of Suceava county with a rapid intervention time represents a percentage of $6.39 \%$ of the total area of the county.

Of course, there are also areas in Suceava county with a poor level of coverage, in which the time for intervention in the case of an emergency situation exceeds 30 minutes. This is the case for the inhabitants of the northwest area of Suceava County: Breaza, Brodina, Cârlibaba, Izvoarele Sucevei, Moldova-Sulița, Moldovița Ulma and Broșteni city in the south of the county. From a statistical point of view, these areas have a total of 22,960 inhabitants, meaning $3.58 \%$ of the entire population of the county. The area of Suceava county with poor coverage level for rapid interventions in case of fires, totals $1698.85 \mathrm{~km}^{2}$, meaning a percentage of 19.93 $\%$.

\section{Conclusions}

This study was achieved using the ArcGIS software and the Network Analyst extension. To be able to realize analyses of this kind, the Emergency Services must buy the ArcGIS program with a license, and the personnel dealing with the use of this software must have at least minimal knowledge of ArcGIS. The methods of analysis used here were based on this software and it would be difficult for people who have never worked with this software before to use it.
In recent years the number of emergencies, from the studied area, has increased rapidly, especially during the summer. Emergency services are equipped with the necessary tools to deal with these emergencies, but often problems occur and prevent the authorized personnel to respond in a timely manner. Among these problems we can mention roads under construction, traffic accidents or trains blocking the access of fire trucks. The identification of vulnerable links in a road network is described in [7].

In the cases of the areas of operation for fires, though covering a larger area, not every emergency station has the necessary equipment to cope with serious crisis situations, and the response time of the military firefighters, situated at great distances increases and with it the damage caused are greater.

The best option to reduce the response time of the emergency services is to use such technologies, and also to have a current and well established database. But these alone are not enough, the condition of the roads in some regions of the county is very poor preventing the emergency services to intervene in time. GIS role in transportation is very important, due to the influence of roads in reduction of the response time, as described in [8].

Likewise, in order to better cover the disadvantaged areas, it is necessary to build other SMURD stations even in settlements with a large number of inhabitants which are far away from the professional centers - settle- 
ments like Dolhasca, Moldovița, Broșteni

and Brodina.

\section{References}

[1]ESRI White Paper, GIS for Fire Station Locations and Response Protocol, USA, 2007.

[2]Lindeskov, C.K., Ambulance allocation using GIS, Technical University of Denmark, Denmark, 2002.

[3] Sapateiro C., Antunes P., An Emergency Response Model Toward Situational Awareness Improvement. The 6th International ISCRAM Conference - Gothenburg, Sweden, 2009.

[4] Vratonjić M., Wittmann H., Using and optimising GIS in an emergency response. European Emergency Association, 2015.

[5] Ganeshkumar, B., Ramesh D., Emergency Response Management and Information System (ERMIS) - A GIS based software to resolve the emergency recovery challenges in Madurai city. International Journal of Geomatics and Geosciences, 2010.

[6] Ntiamoah B., Emergency response time and a transportation model to improve emergency services in Henry County, Indiana, SUA, 2009.

[7] Taylor, M.A.P., Critical transport infrastructure in urban areas: impacts of traffic incidents assessed using accessibility based network vulnerability analysis. Growth and Change, 593-616, 2008.

[8] Pasha I., Ambulance management system using GIS, Department of Computer and Information Science Linköping University SE-581 83 Linköping, Sweden, 2006. 